\title{
Study on seroprevalence and serotyping of foot and mouth disease in Chad
}

\author{
M. Ouagal (1), E. Brocchi (2), S. Grazioli ${ }^{(2)}$, A. Ben Youssef ${ }^{(3)}$, K. Sumption ${ }^{(3)}$, D. Kiram ${ }^{(4)}$, \\ A. Oussiguéré ${ }^{(1)}$, P. Hendrikx ${ }^{(5)}$, D. Berkvens ${ }^{(6,7)} \&$ C. Saegerman ${ }^{(8)^{*}}$ \\ (1) Ministère de l'Élevage, Institut de Recherche en Élevage pour le Développement, PO Box 433, Route de Farcha, N'Djamena, \\ Chad \\ (2) Istituto Zooprofilattico Sperimentale della Lombardia e dell'Emilia Romagna (IZSLER), 9 Via Bianchi, 25024 Brescia, Italy \\ (3) European Commission for the Control of Foot and Mouth Disease (EuFMD), Food and Agriculture Organization of the United \\ Nations (FAO), Room C-518, Viale delle Terme di Caracalla, 00100 Rome, Italy \\ (4) Ministère de l'Élevage, Direction Générale de la Planification et du Renforcement des Capacités, P0 Box 750, Route de \\ Farcha, N'Djamena, Chad \\ (5) Unité de coordination et d'appui à la surveillance, Agence nationale de sécurité sanitaire de l'alimentation, de \\ I'environnement et du travail (ANSES), 31 avenue Tony Garnier, 69364 Lyon Cedex 07, France \\ (6) Institute of Tropical Medicine, Department of Biomedical Sciences, Nationalestraat 155, B-2000 Antwerp, Belgium \\ (7) Department of Animal Production, Faculty of Bio-Science Engineering, University of Ghent, Coupure Links 653, B-9000 Ghent, \\ Belgium \\ (8) Research Unit in Epidemiology and Risk Analysis Applied to Veterinary Sciences (UREAR-ULg), Fundamental and Applied \\ Research for Animal and Health (FARAH) Center, Department of Infectious and Parasitic Diseases, Faculty of Veterinary Medicine, \\ University of Liège, B42, Quartier Vallée 2, Avenue de Cureghem 7A, B-4000 Liège, Belgium \\ *Corresponding author: claude.saegerman@uliege.be
}

\section{Summary}

Foot and mouth disease (FMD) is a highly contagious viral disease that affects all Artiodactyla. Seven immunologically distinct serotypes of FMD virus (FMDV) exist. In Chad, although FMD is included in the list of diseases monitored by the Chadian Animal Disease Surveillance Network (REPIMAT), the epidemiological situation remains unclear. A serological survey was conducted in the cattle population in eight of the nine administrative regions of the country (those regions with the highest cattle densities), to evaluate the prevalence and serotypes of circulating FMDV. A total of 796 sera from randomly selected cattle were analysed at the World Organisation for Animal Health/Food and Agriculture Organization of the United Nations FMD Reference Laboratory at the Istituto Zooprofilattico Sperimentale della Lombardia e dell'Emilia Romagna (IZSLER), in Brescia (Italy). An enzyme-linked immunosorbent assay (ELISA), called 3ABC ELISA, was used to detect antibodies against non-structural proteins (NSPs), as well as a series of six competitive ELISAs to detect and serotype antibodies against the structural proteins of FMDV serotypes 0 , A, SAT 1, SAT 2, Asia 1 and C.

Based on the detection of anti-NSP antibodies, the animal-level seroprevalence was $35.6 \%$ (95\% confidence interval [CI]: $32.2-38.9)$ and the herd-level seroprevalence was $62.3 \%(95 \%$ Cl: 53.0-71.5). FMD was present in all livestock administrative divisions surveyed, with a higher prevalence in southern regions, which are characterised by higher rainfall and humidity and more important transboundary animal movements. Cattle aged more than four years had a higher seroprevalence, which may be due to repeated exposure. Semi-sedentary farming and transhumance were also risk factors. Antibodies against serotypes A, 0, SAT 1 and SAT 2 were detected.

\section{Keywords}

Cattle - Chad - FMD - Foot and mouth disease - Seroprevalence - Serotype - Virus.

\section{Introduction}

Livestock are an important source of income in most developing countries. In Africa, they often contribute up to $10-20 \%$ of the gross national product (1). In Chad, livestock contribute $80 \%$ of the agricultural capital stock (US\$ 6,912 million in 2007), i.e. 59.1\% of livestock fixed assets, $10.4 \%$ of livestock inventory, and $10.7 \%$ of structures for livestock (2). In Chad, the rural population represents $72.4 \%$ of the whole population and livestock is the secondlargest source of foreign exchange earnings after oil (3). The livestock sector provides a livelihood for $40 \%$ of the rural population and accounts for 30\% of Chad's exports (over $50 \%$, excluding oil). Annual revenue streams in this sector are estimated at US\$ 257 million (4). The livestock system 
is pastoral and based on mobility. This system is used for $80 \%$ of the cattle population (3). Animal diseases remain one of the major constraints to the development of this sector, including foot and mouth disease (FMD) $(5,6)$.

Foot and mouth disease is a highly contagious, transboundary, viral disease, affecting both domestic and wild Artiodactyla $(7,8,9)$. There are seven serotypes $(\mathrm{O}, \mathrm{A}, \mathrm{C}$, SAT 1 , SAT 2 , SAT 3 and Asia 1) and several subtypes with a worldwide distribution $(10,11,12)$. Only five of the seven serotypes occur on the African continent. Serotype Asia 1 has not been observed in Africa and serotype $C$ is extinct, in that it has not been seen for more than 14 years (13).

Foot and mouth disease is one of the major transboundary diseases, responsible for causing considerable economic losses, not only when it (re-)emerges in previously diseasefree areas but also in areas to which it is endemic $(9,13,14$, $15,16)$. Clinically, FMD is characterised by pyrexia (up to $42^{\circ} \mathrm{C}$ ), dullness, the presence of blisters and inappetence. In cattle, FMD is characterised by fever, a drop in milk production, and vesicles or blisters that appear in the mouth, on the teats and between the hooves. Hypersalivation, difficulty in swallowing, acute lameness and/or difficulty in walking accompany the lesions.

In epidemiological terms, FMD reaches morbidity of close to $100 \%$ and a mortality rate of about $5 \%$ when it (re-) emerges in disease-free areas. Mortality usually takes place in young animals as a result of myocarditis, so-called 'tiger heart disease' (17).

Antibodies are found in a large proportion of animals kept under extensive husbandry, a production system characteristic of most countries in western and central Africa. Since FMD causes more losses in intensive husbandry systems, such as intensive dairy farms on the periphery of towns, these farms are usually targeted for vaccination campaigns (18).

A more accurate knowledge of the epidemiology and impact of FMD in traditional farming systems in sub-Saharan Africa is a prerequisite when evaluating and adapting control programmes, such as those advocated by the World Organisation for Animal Health (OIE) and the Food and Agriculture Organization of the United Nations (FAO) $(19,20)$. According to the World Reference Laboratory for FMD (WRLFMD) at the Pirbright Institute (www.wrlfmd. org), there are few historical accounts of FMD outbreaks in Chad: serotype A was first reported in 1973 and serotype SAT 1 in 1963, 1964 and 1972. FMD has been included in the list of monitored diseases of the Chadian Animal Disease Surveillance Network since the Network's creation in 1995 (the Réseau d'Épidemiosurveillance des Maladies Animales au Tchad or REPIMAT). REPIMAT surveillance of FMD $(6,21)$ is passive and primarily targets cattle because of their importance to the country's economy (21). FMD is the most reported disease to REPIMAT (5). However, the national laboratory is unable to analyse suspected FMD samples, due to a lack of trained personnel and the necessary equipment and materials. For this reason, FMD notification is limited to clinical suspicion without laboratory confirmation (6). The epidemiological situation of the disease thus remains unclear in the absence of any identification of FMDV serotype(s) circulating in the country. There has never been any FMD vaccination in Chad.

This present retrospective aims to evaluate the seroprevalence of FMD and assess the presence of specific antibodies directed against FMDV serotypes in Chad in early 2010, based on randomised historical serum samples.

\section{Materials and methods}

\section{Survey area and sampling design}

Chad has three main regions: a desert zone in the north, an arid Sahelian belt in the centre and a more fertile Sudanian savanna zone in the south. The survey area is depicted in Figure 1. Most herders are mobile pastoralists. Among the breeds of cattle raised in Chad are the white Fulani, red Fulani, white Lake Chad, Tupuri and Sokoto (22).

Two-stage random sampling was conducted to gather samples. The primary unit was the village (an epidemiological unit equivalent to the herd in the African context; i.e. with an absence of fences) and the secondary unit was the individual animal.

A total of 106 villages were randomly drawn from the 3,297 villages in the study area (involving eight breeding delegations) (Fig. 1). These villages were distributed over various geographic areas which were covered by 34 active REPIMAT surveillance posts. This should make it possible to detect herd seroprevalence of FMD of 50\% (no a priori knowledge is available), with an absolute precision of $10 \%$ and a confidence level of $95 \%$ (plus a reserve of $10 \%$ of samples in case some breeders declined to take part). The regional livestock delegation from the north was not included in this survey because the surveillance posts were no longer functional due to a lack of agents. In addition, this area is largely desert and cattle breeding here is of relatively low importance compared to in other delegations.

An average of seven to eight cattle per village were randomly selected from animals aged one year and over, of both sexes. No vaccination against FMD has been carried out in Chad so far. A total of 796 randomly selected cattle were sampled without gender stratification; 628 were between one and four years old and 168 were more than four years of age. 


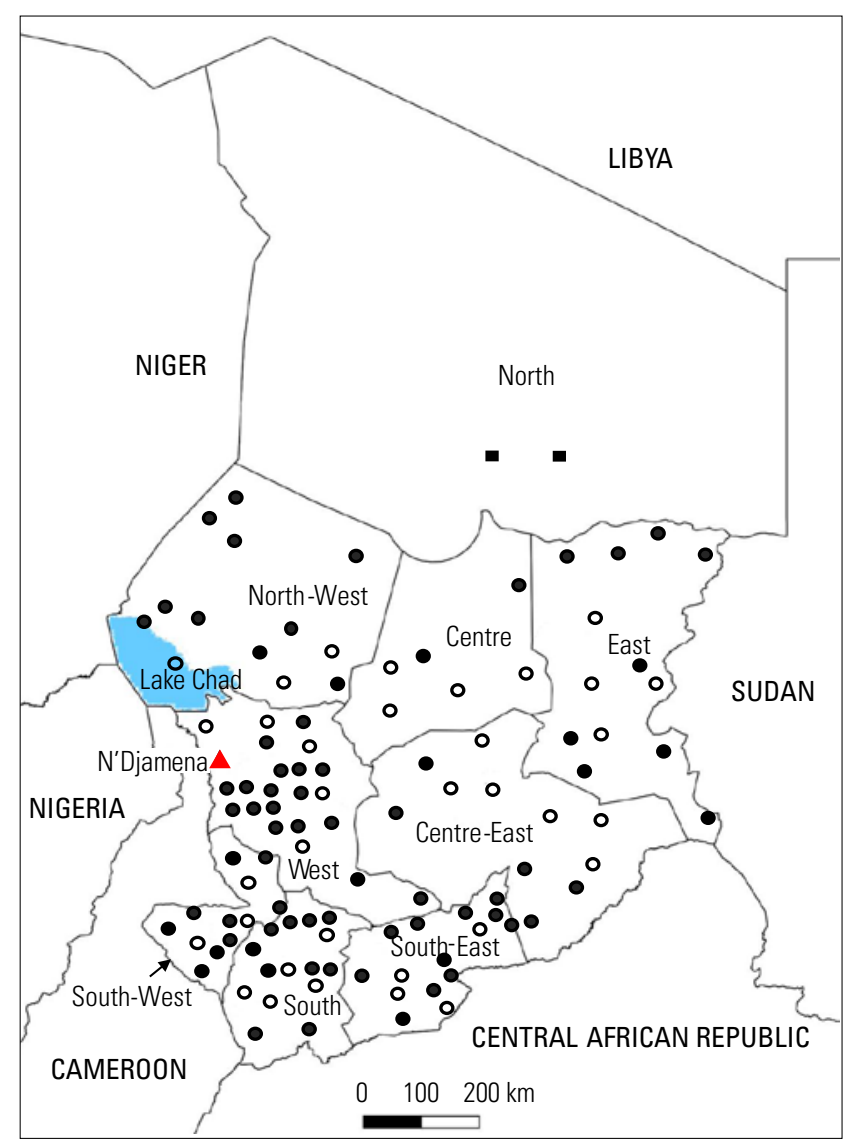

- Posts became non-functional in the northern delegation and were not retained $(n=2)$ - Functional surveillance posts that did not participate in sampling for this study $(n=72)$ - Functional surveillance posts that participated in sampling for this study $(n=34)$ from 106 villages, randomly drawn from 3,277 villages in total. These 106 villages are distributed across various geographical areas, covered by 34 active surveillance posts. - Capital of Chad

Fig. 1

Location of the 106 Chadian Animal Disease Surveillance Network posts, by livestock administrative division

\section{Blood collection}

Blood sampling was conducted between December 2009 and February 2010. Jugular vein blood was collected in 5-ml Vacutainers ${ }^{\circledR}$. Samples were kept at an ambient temperature for two to three hours to induce clotting. After removal of the coagulate, the serum was preserved on ice until its arrival at the Institut de Recherche en Élevage pour le Développement, in N'Djamena (Farcha Laboratory). The samples were centrifuged at 3,000 revolutions per minute (rpm), aliquoted in cryotubes (Nalgenes ${ }^{\circledR}$ ) and stored at $-20^{\circ} \mathrm{C}$ until transportation to the laboratory where analysis was carried out. The international requirements imposed on the transport of dangerous infectious materials were strictly adhered to during transportation from Chad to the analysing laboratory in Italy.

\section{Serological testing}

The samples were analysed at the Istituto Zooprofilattico Sperimentale della Lombardia e dell'Emilia Romagna (IZSLER), in Brescia, Italy, an OIE/FAO FMD Reference Centre.

The tests, developed at IZSLER, consisted of:

- an ELISA for the detection of antibodies against NSPS, abbreviated in the text as the '3ABC ELISA'. Antibodies are elicited after an infection and are common to all FMDV serotypes

- a series of six 'in-house' competitive ELISAs for the detection and serotyping of antibodies against the structural proteins (SPs) of FMDV serotypes O, A, SAT 1, SAT 2, Asia 1 and $C$, to indirectly identify the viral serotypes circulating in Chad. IZSLER did not test for SAT 3.

\section{Non-structural protein enzyme-linked immunosorbent} assay

The serological assay used to detect anti-NSP antibodies was the previously validated 3ABC-trapping ELISA (23), in the form of a ready-to-use kit, with pre-sensitised ELISA immunoplates, peroxidase-conjugated antiruminant immunoglobulin G ( $\operatorname{Ig} G$ ), control sera, and the 3,3',5,5'-tetramethylbenzidine chromogen, produced at IZSLER. The specificity of this NSP ELISA exceeds $99 \%$, while sensitivity varies, depending on the time lapse after infection and on previous vaccination status. Sensitivity of $100 \%$ can be achieved for non-vaccinated cattle exposed to infection, while $86.4 \%$ can be achieved for the detection of carriers among vaccinated cattle (23).

\section{Monoclonal antibody-based, solid-phase, competitive, enzyme-linked immunosorbent assay}

The principle behind and the procedure for the monoclonal antibody (MAb)-based, solid-phase, competitive ELISA (SPCE) is described below. SPCEs were first used to quantify antibodies specific to the European FMDV subtypes O1, A5 and $\mathrm{Cl}$ (24), and later applied to other infectious diseases $(25,26)$. Afterwards, the test reagents used for serotype $O$ and A ELISAs, i.e. FMDV-specific MAbs and antigens, were adapted and validated to detect antibodies more closely related to currently used vaccine strains or circulating serotypes and variants. In particular, the updated ELISAs used FMDV antigens from the vaccine strains $\mathrm{Ol}$ Manisa and A22 Iraq. Each was respectively associated with a competing detector MAb characterised by broad intra-type reactivity. Similar ELISAs for the detection of antibodies against serotypes Asia 1, SAT 1 and SAT 2 have been described more recently $(27,28)$.

Briefly, the assay procedure for each SPCE was as follows: immunoplates were coated with $50 \mu$ per well of a type- 
specific catching MAb at a saturating dilution in carbonate/ bicarbonate buffer of $\mathrm{pH} 9.6$ by overnight incubation at $4^{\circ} \mathrm{C}$. After three washes, $50 \mu \mathrm{l}$ of FMDV antigen of the homologous serotype was placed in each well at a predetermined optimal dilution.

After $1 \mathrm{~h}$ of incubation at $37^{\circ} \mathrm{C}$ and washing, $50 \mu \mathrm{l}$ of a series of three-fold dilutions of test and control sera was incubated with the trapped antigen for $1 \mathrm{~h}$ at $37^{\circ} \mathrm{C}$. Then, $25 \mu \mathrm{l}$ per well of the homologous peroxidase-conjugated competitor/detector MAb was added to each well and plates were incubated at $37^{\circ} \mathrm{C}$ for a further $1 \mathrm{~h}$. After a last series of washes, the colorimetric reaction was developed by distributing $50 \mu \mathrm{l}$ per well of the substrate solution: $0.5 \mathrm{mg} / \mathrm{ml}$ of $o$-phenylenediamine dihydrochloride (OPD) in phosphate-citrate buffer, $\mathrm{pH} 5$, containing $0.02 \% \mathrm{H}_{2} \mathrm{O}_{2}$.

The reaction was stopped after $10 \mathrm{~min}$ by adding $50 \mu \mathrm{l}$ of $2 \mathrm{~N} \mathrm{H}_{2} \mathrm{SO}_{4}$ and the optical density values (ODs) were read at a 492-nm wavelength. The optimal working dilution of antigen and peroxidase-conjugated MAb, giving a spectrophotometric reading of $1.5 \mathrm{OD}$, was predetermined by chequer-board titrations. The screening dilution for sera was $1 / 10$; the endpoint titres of positive sera were expressed as the reciprocal of the highest serum dilution providing $50 \%$ inhibition.

\section{Statistical analysis}

Data were entered into a spreadsheet using the program Microsoft Excel ${ }^{\circledR}$ 2010. Statistical analysis was carried out in Stata/MP 14.2 (29). A Poisson regression (or a negative binomial regression, when required, due to extra-binomial variability) was used, followed by a Bonferroni corrected multiple test, if appropriate. A chi-square test was used to test the association between management type and seroprevalence. A level of significance of $5 \%$ was used throughout (divided by the number of tests performed for the Bonferroni correction).

\section{Results}

Out of 796 samples tested in the 3ABC ELISA, 283 yielded a positive result, amounting to an animal seroprevalence of $35.6 \%$ (95\% confidence interval [CI]: 32.2-38.9). The seroprevalence was geographically heterogeneous, varying significantly according to the livestock administrative division. The southern and central divisions showed a higher seroprevalence than the others. In addition, the East and Central East divisions showed a lower seroprevalence (less than 20\%) than the other divisions (Table I). The overall average herd-level seroprevalence was $62.9 \%$ (95\% CI: 53.0-71.5).

As shown in Table II, a significantly higher seroprevalence was recorded in older animals $(p<0.001)$.

Table III shows seroprevalence by production type. A significantly higher seroprevalence (chi square $=4.12$, $p=0.042$ ) was recorded in transhumant and semi-sedentary herds, compared to that found in sedentary herds.

Out of the 796 sera tested for antibodies against the SPs of six FMDV serotypes, 480 (60\%) scored positive for one or more serotypes. In 278 positive sera, the FMDV serotype responsible for the infection was identified as type $\mathrm{O}, \mathrm{A}$, SAT 1 or SAT 2, based on the detection of antibody against a single serotype or antibody titres that were significantly higher against one serotype. Another 200 samples showed similar levels of antibodies against two or more serotypes

Table I

Seroprevalence of foot and mouth disease in Chad, by administrative division (antibodies against non-structural proteins)

\begin{tabular}{|c|c|c|c|c|c|}
\hline $\begin{array}{l}\text { Administrative } \\
\text { division of Chad }\end{array}$ & $\begin{array}{c}\text { Number of samples } \\
\text { analysed }\end{array}$ & $\begin{array}{c}\text { Number of positive } \\
\text { samples }\end{array}$ & Prevalence (\%) & $95 \% \mathrm{Cl}$ & Multi-test $^{(\mathrm{a})}$ \\
\hline Centre & 43 & 19 & 44.2 & $(29.4-59.0)$ & $a b$ \\
\hline Centre-East & 111 & 17 & 15.3 & (8.6-22.0) & $c d$ \\
\hline East & 83 & 5 & 6.0 & $(0.9-11.1)$ & D \\
\hline North-West & 126 & 38 & 30.2 & $(22.2-38.2)$ & $c d$ \\
\hline West & 87 & 21 & 24.1 & $(15.1-33.1)$ & bcd \\
\hline South & 128 & 51 & 39.8 & $(31.3-48.3)$ & $a b$ \\
\hline South-East & 138 & 86 & 62.3 & $(54.2-70.4)$ & A \\
\hline South-West & 80 & 46 & 57.5 & (46.7-68.3) & A \\
\hline Total & 796 & 283 & 35.6 & (32.3-38.9) & \\
\hline
\end{tabular}

a) Regions with different letters are significantly different from each other $(p<0.05$, with Bonferroni correction)

Cl: confidence interval 
Table II

Seroprevalence of foot and mouth disease (antibodies against non-structural proteins), according to age of animals

\begin{tabular}{lcccc}
\hline Age stratum & $\begin{array}{c}\text { Number of } \\
\text { sera tested }\end{array}$ & $\begin{array}{c}\text { Number of } \\
\text { positive } \\
\text { sera }\end{array}$ & $\begin{array}{c}\text { Prevalence } \\
\%\end{array}$ & $\mathbf{9 5 \%} \mathbf{C l}$ \\
\hline$<4$ years & 628 & 191 & 30.4 & $(26.8-34.0)$ \\
$>4$ years & 168 & 92 & 54.8 & $(47.2-62.3)$ \\
Total & $\mathbf{7 9 6}$ & $\mathbf{2 8 3}$ & $\mathbf{3 5 . 6}$ & $\mathbf{( 3 2 . 2 - 3 8 . 9 )}$ \\
\hline
\end{tabular}

Cl: confidence interval

from O, A, SAT 1 or SAT 2 (Table IV). In contrast, the seropositivity levels for serotypes Asia 1 and $C$ were very low (22 out of 296 sera tested weakly positive for FMDV Asia 1 and only six out of 796 tested borderline positive for type C) and could reasonably be attributed to cross-reactive antibodies.

\section{Discussion}

There is a clear need for FMD risk-based surveillance to determine the status and factors that influence disease dissemination in areas where FMD is endemic, such as African countries, and to target appropriate control strategies. Under the auspices of the FAO and OIE, some African regions have embarked on a progressive control pathway (PCP) for the control of $\operatorname{FMD}(20,30)$. The success of any FMD control campaign depends on many factors (13):
Table III

Seroprevalence of foot and mouth disease (antibodies against non-structural proteins), according to type of farm production

\begin{tabular}{lcccc}
\hline $\begin{array}{l}\text { Type of farm } \\
\text { production }\end{array}$ & $\begin{array}{c}\text { Number } \\
\text { of sera } \\
\text { tested }\end{array}$ & $\begin{array}{c}\text { Number of } \\
\text { positive } \\
\text { sera }\end{array}$ & $\begin{array}{c}\text { Prevalence } \\
\mathbf{\%}\end{array}$ & $\mathbf{9 5 \%} \mathbf{~ C l}$ \\
\hline Sedentary & 690 & 236 & 34.2 & $(30.7-37.7)$ \\
Semi-sedentary & 70 & 29 & 41.4 & $(29.9-53.0)$ \\
Transhumant & 36 & 18 & 50.0 & $(33.7-66.3)$ \\
Total & $\mathbf{7 9 6}$ & $\mathbf{2 8 3}$ & $\mathbf{3 5 . 6}$ & $\mathbf{( 3 2 . 2 - 3 8 . 9 )}$ \\
\hline Cl: confidence interval & & & &
\end{tabular}

- the specific epidemiology of the disease in areas of interest

- the local and regional surveillance programmes monitoring circulating FMDV

- a vaccine that includes strain(s) that antigenically match the circulating strain(s)

- the potency of the vaccine

- vaccine coverage

- rapid vaccine implementation

- the planning and management of the vaccination campaign by a well-resourced Veterinary Service

- the involvement and cooperation of livestock farmers.

Chad's current status along the PCP for FMD is stage 0 (on a scale ranging from 0 to 5), corresponding to an uncontrolled risk of FMD, with no reliable information $(13,20)$. Consequently, there is a crucial need for reliable epidemiological information on FMD in Chad, where the

Table IV

Prevalence of antibodies against foot and mouth disease serotypes in Chad, by administrative division

\begin{tabular}{|c|c|c|c|c|c|c|c|}
\hline \multirow{2}{*}{$\begin{array}{l}\text { Administrative } \\
\text { division in Chad }\end{array}$} & \multirow{2}{*}{$\begin{array}{c}\text { Number of sera } \\
\text { tested }\end{array}$} & \multicolumn{4}{|c|}{ Number of sera positive by serotype (a) } & \multirow{2}{*}{$\begin{array}{c}\text { Number of sera } \\
\text { that cross-react } \\
\text { with multiple } \\
\text { serotypes }^{(b)}\end{array}$} & \multirow{2}{*}{$\begin{array}{c}\text { Number of sera tha } \\
\text { test negative for all } \\
\text { serotypes }\end{array}$} \\
\hline & & $\mathbf{0}$ & A & SAT 1 & SAT $2^{\text {(c) }}$ & & \\
\hline Centre & 43 & 13 & 1 & 4 & 2 & 4 & 19 \\
\hline Centre-East & 111 & 13 & 0 & 20 & 3 & 5 & 70 \\
\hline East & 83 & 7 & 0 & 18 & 4 & 4 & 50 \\
\hline North-West & 126 & 8 & 10 & 13 & 10 & 27 & 58 \\
\hline West & 87 & 3 & 11 & 13 & 2 & 8 & 50 \\
\hline South & 128 & 5 & 15 & 16 & 15 & 39 & 38 \\
\hline South-East & 138 & 6 & 11 & 5 & 19 & 77 & 20 \\
\hline South-West & 80 & 9 & 17 & 2 & 3 & 36 & 13 \\
\hline Total (\%) & 796 & $64(8.0 \%)$ & $65(8.2 \%)$ & $91(11.4 \%)$ & $58(7.3 \%)$ & $200(25.1 \%)$ & $318(40 \%)$ \\
\hline
\end{tabular}

a) Positivity for a single serotype or antibody titre that is three-fold higher or more against a single serotype b) Number of sera showing cross-reactivity for two or more serotypes c) 0, A, SAT 1 and SAT 2 are foot and mouth disease virus serotypes 
disease is endemic. As a result of the lack of local diagnostic laboratory expertise and the cost of reagents for FMD diagnosis, only clinical suspicions without laboratory confirmation are recorded by the surveillance network, REPIMAT (6).

The overall seroprevalence estimated in 2010 at the individual level (35.6\%) and at the herd level (62.3\%) highlights the gravity of FMDV circulation in Chad. Considering this high level of FMD seroprevalence and the common transhumant system in Chad (involving 80\% of cattle), there is an important risk of spreading FMD through cattle movements over long distances (FMD 'trans-pool' movement). In consequence, at least two main options must be evaluated when attempting to control FMD. First, animal movement controls must be imposed to try to prevent the movement of FMDV. However, the practicality of this option is questionable as transhumance is an ancestral practice and increases the resilience of livestock (through the search for nutritive resources due to climatic conditions) and their associated population health. The second course of action is a vaccination campaign for livestock, but this requires a much better knowledge of the FMDV serotypes currently circulating throughout Africa, especially in countries that practise transhumance, to select the appropriate vaccine (thus requiring a regional approach to FMD control). In addition, more field information is needed on persistently infected carriers after vaccination. More transdisciplinary research (e.g. in anthropology, sociology, infectiology, epidemiology and economics) is also required to produce evidence-based information that will help decision-makers to choose the best option(s) for controlling FMD in Africa.

These high seroprevalence results, especially in the southern part of Chad, are probably due to a range of factors. Among them are:

- intense animal movements (80\% of cattle are kept under a transhumant husbandry system), resulting in frequent contacts between different herds

- a more humid climate (rainfall of 800-1,200 mm/year), allowing longer virus survival outside the host

- the presence of wildlife (e.g. buffalo, antelope and warthogs), which can serve as reservoirs of the virus, in and around the numerous game reserves in the area (which generally have established boundaries but are not fenced).

Wildlife density is more important in the reserves to the south of the country, especially in Zakouma National Park. It is during the hot, dry season (March to April) that contact with livestock occurs frequently. This zone, rich in lush pastures, continuously has a high concentration of livestock, with herds coming from the whole of the Chadian territory, as well as from neighbouring countries (Cameroon and the Central African Republic) (11).
The role of game animals in the epidemiology of FMD has previously been investigated in Chad; in particular, in Zakouma National Park (12). In this study, blood samples from buffalo $(n=53)$ and other wildlife $(n=203)$ were collected from 1999 to 2003. Based on the detection of anti-NSP antibodies, the seroprevalence of FMD was estimated at 23.1\% (mainly in Nile buffalo, Syncerus caffer aequinoctialis). Subsequently, the presence of specific antibodies against different serotypes of FMDV (A, O, C, SAT 1, SAT 2 and SAT 3) was evaluated in a subset of 30 sera, using SPCE. Positive responses were observed, in descending order, for serotypes SAT 2 (13/30), O (9/30), SAT 1 and C (2/30) (12).

The same serotypes found in the present study involving cattle were also recorded in a retrospective study by Di Nardo et al. (12), involving wildlife species (mainly buffalo). More investigations are needed to better understand the role of wildlife in FMD epidemiology in Chad. In addition, the lower seroprevalence observed in the East and Central East divisions is likely due to the low livestock density and fewer movements of animals in these areas.

The present study also shows a link between age and seroprevalence. Animals aged more than four years have a higher probability of being seropositive, probably due to a higher chance of having come into contact with the virus. A similar trend was observed in Ethiopia (31). While the inherent logic of this observation is obvious (by definition, older animals have had more opportunity to be exposed to FMDV during their lifetime), husbandry practices probably also have some influence. Young animals are kept around the camp while only older animals are trekked over long distances in search of pastures and water. This higher risk of being exposed to FMDV also means that older animals are more likely to become infected with different serotypes.

The results demonstrate the presence of serotypes A, O, SAT 1 and SAT 2, while the very low levels of antibodies that react against serotypes Asia 1 and $C$ are attributable to inter-type cross-reaction. In fact, ELISAs to detect antibodies against SPs suffer from imperfect type specificity, and cross-reactions may occur among all FMDV serotypes (32). However, the significantly higher proportion of sera that cross-react with two or more of the first four serotypes is also suggestive of multiple infections with different serotypes. Indeed, these four serotypes are regularly recorded in Africa $(9,14)$, where the diffusion of the various serotypes is essentially determined by uncontrolled animal movement (14).

The importance of husbandry is also reflected in the higher seroprevalence values obtained from transhumant and semi-sedentary herds, when compared to those of sedentary animals (Table III). This higher probability of exposure to 
the virus also means that older animals harbour antibodies against a larger variety of serotypes, given that infection with one FMDV serotype does not protect against infection with other serotypes.

This is also reflected by the similar percentages of different serotypes observed in the results. In Cameroon, serotypes O, SAT 1 and SAT 2 have been identified (33). The global FMD situation is characterised by seven regional pools of dominant serotypes $(11,13)$. Chad is classified in the fifth pool, with serotypes A, O, SAT 1 and SAT 2. The authors' results corroborate this classification. FMDV type $C$ had a limited distribution compared to most of the other serotypes and has not been reported since 2004. Serotype Asia 1 has thus far never been reported in Africa (13). Serotype SAT 3 is present only in pools 4 (East Africa) and 6 (South Africa), and geographically close to the countries comprising pool 5 (West/Central Africa), which include Chad (11). Given the uncontrolled introduction of animals and animal products into Chad, the incursion of type SAT 3 cannot be ruled out. Further study of SAT 3 may be warranted, as this serotype has recently been recorded in sera from West and Central Africa (e.g. 34) and from eastern Africa (e.g. 35).

This study has some limitations that are worth mentioning. The principal shortcoming is the period of the study (late 2009 to early 2010) when no records on laboratory confirmation of FMD outbreaks could be found in the statistics of the Ministry of Agriculture and Livestock. The only laboratory findings confirming FMD outbreaks in Chad are those of the WRLFMD and the last confirmed date is in 1973. A lack of local diagnostic laboratory expertise, the high cost of reagents for FMD diagnosis, a limited number of field staff, the cost of FMD vaccine, and the lack of a national and/or regional strategy for FMD surveillance and control are reasons frequently invoked (20).
Since the present study, some interesting initiatives have been taken to improve the situation, including the establishment of a laboratory network with support from the European Commission (EC) for the Control of FMD (EuFMD); the organisation of training seminars for FMD laboratories in Mauritania, Niger and Chad in May 2012; and the provision of diagnostic kits (ELISAs) to each laboratory for local typing (20). Continuing such action (capacity-building, serological survey, isolating circulating FMDV strains) is strongly recommended in Chad and, more generally, across all of sub-Saharan Africa.

Despite such limitations, this study has clearly demonstrated the presence of antibodies directed against NSPs of FMDV in Chad, and shown that serotypes O, A, SAT 1 and SAT 2 were present there in 2010, on the basis of the prevalence of the serotype-specific antibodies identified. Epidemiological information obtained during this study has provided important insights for planning a control strategy. However, further similar studies are needed, including research into virus isolation and sequencing and studies of other highly sensitive species in Chad, including sheep, goats, pigs, camels and buffalo, if we are to come to a fuller understanding of the struggle against FMD.

\section{Acknowledgements}

The authors sincerely thank the Belgian Directorate General for Development Cooperation for financially supporting this study. They also gratefully recognise the financial support of the European Commission for the Control of Foot and Mouth Disease (EuFMD) in covering transport expenses and the IZSLER laboratory for serological analysis of the samples. Moreover, they wish to acknowledge the logistic support of the Institut de Recherches en Élevage pour le Développement in N'Djamena.

\title{
Prévalence sérologique de la fièvre aphteuse au Tchad et sérotypage
}

\author{
M. Ouagal, E. Brocchi, S. Grazioli, A. Ben Youssef, K. Sumption, D. Kiram, \\ A. Oussiguéré, P. Hendrikx, D. Berkvens \& C. Saegerman
}

\section{Résumé}

La fièvre aphteuse est une maladie virale extrêmement contagieuse qui affecte l'ensemble des artiodactyles. Sept sérotypes du virus de la fièvre aphteuse ont été répertoriés, qui sont distincts au plan immunologique. Au Tchad, bien que la fièvre aphteuse figure sur la liste des maladies visées par le Réseau d'épidémiosurveillance des maladies animales du Tchad (REPIMAT), la situation épidémiologique demeure mal connue. Une enquête sérologique a été réalisée dans la population bovine de huit régions administratives sur les neuf que compte le pays (afin de couvrir les régions 
où la densité de la population bovine est la plus élevée), dans le but d'évaluer la prévalence du virus de la fièvre aphteuse et de caractériser les sérotypes présents. Au total, 796 sérums prélevés sur des bovins sélectionnés de manière aléatoire ont été analysés au Laboratoire de référence pour la fièvre aphteuse de l'Organisation mondiale de la santé animale/Organisation des Nations Unies pour l'alimentation et l'agriculture à I'Istituto Zooprofilattico Sperimentale della Lombardia e dell'Emilia Romagna (IZSLER) de Brescia (Italie). Les anticorps dirigés contre les protéines non structurales ont été détectés au moyen d'une épreuve immuno-enzymatique $3 A B C$ (ELISA $3 A B C$ ) tandis qu'une série de six ELISA de compétition a permis de détecter et de caractériser les anticorps spécifiques des protéines structurales des sérotypes 0, A, SAT 1, SAT 2, Asia 1 et $C$ du virus de la fièvre aphteuse.

D'après les résultats de la détection d'anticorps dirigés contre les protéines non structurales, la prévalence sérologique à l'échelle individuelle était de $35,6 \%$ (avec un intervalle de confiance [IC] à $95 \%$ de 32,2 à 38,9 ) tandis que la prévalence à l'échelle des troupeaux s'élevait à $62,3 \%$ (IC à $95 \%$ de 53,0 à 71,5 ). La fièvre aphteuse était présente dans chacune des divisions administratives étudiées, avec une prévalence plus élevée dans les régions méridionales, qui se caractérisent par des précipitations et une hygrométrie plus fortes et par l'importance des mouvements transfrontaliers d'animaux. La prévalence sérologique était plus élevée chez les bovins âgés de plus de quatre ans, ce qui s'explique probablement par un nombre répété d'expositions. Le rôle de l'élevage semi-sédentaire et de la transhumance en tant que facteurs de risque a été mis en lumière. Les anticorps détectés étaient dirigés contre les sérotypes $A, 0$, SAT 1 et SAT 2.

\title{
Mots-clés
}

Bovins - Fièvre aphteuse - Prévalence sérologique - Sérotype - Tchad - Virus.

-

\section{Estudio de la seroprevalencia y determinación de serotipos de la fiebre aftosa en el Chad}

\author{
M. Ouagal, E. Brocchi, S. Grazioli, A. Ben Youssef, K. Sumption, D. Kiram, \\ A. Oussiguéré, P. Hendrikx, D. Berkvens \& C. Saegerman
}

\section{Resumen}

La fiebre aftosa es una patología vírica muy contagiosa que afecta a todos los artiodáctilos. Existen siete serotipos inmunológicamente diferenciados del virus que la causa. En el Chad, aunque la fiebre aftosa figura en la lista de enfermedades sometidas a vigilancia por la Red Chadiana de Vigilancia Zoosanitaria (REPIMAT), la situación epidemiológica de la enfermedad sigue rodeada de incertidumbre. Los autores describen un estudio serológico realizado en la población vacuna de ocho de las nueve regiones administrativas del país (las que presentan la mayor densidad de ganado vacuno) con objeto de determinar la prevalencia y los serotipos del virus de la fiebre aftosa circulante. Tras seleccionar aleatoriamente un total de 796 cabezas de ganado y obtener de ellas muestras de suero, estas fueron analizadas en el Istituto Zooprofilattico Sperimentale della Lombardia e dell'Emilia Romagna (IZSLER) de Brescia (Italia), que es el Laboratorio de Referencia de la Organización Mundial de Sanidad Animal y la Organización de las Naciones Unidas para la Alimentación y la Agricultura para la fiebre aftosa. Para detectar anticuerpos dirigidos específicamente contra proteínas no estructurales se empleó un ensayo 
inmunoenzimático (ELISA) denominado ELISA $3 A B C$, a lo que se agregó una serie de seis técnicas ELISA de competición concebidas para detectar y tipificar anticuerpos dirigidos contra las proteínas estructurales de los serotipos $0, A$, SAT 1, SAT 2, Asia 1 y $C$ del virus de la fiebre aftosa.

A tenor de los niveles detectados de anticuerpos contra proteínas no estructurales, la seroprevalencia individual era de un 35,6\% (intervalo de confianza [IC] al 95\%: $32,2-38,9$ ) y la seroprevalencia de rebaño era de un $62,3 \%$ (IC $95 \%$ : $53,0-71,5$ ). La fiebre aftosa, presente en todas las divisiones administrativas ganaderas estudiadas, alcanzaba sus máximos niveles de prevalencia en las regiones meridionales, caracterizadas por tasas de pluviosidad y humedad más altas y por un mayor volumen de movimientos transfronterizos de animales. La seroprevalencia era más elevada en los ejemplares de más de cuatro años de edad, hecho que puede deberse a exposiciones reiteradas. La producción ganadera en régimen semisedentario y la trashumancia eran también factores de riesgo. Se detectaron anticuerpos contra los serotipos A, 0, SAT 1 y SAT 2.

\section{Palabras clave}

Chad - Fiebre aftosa - Ganado vacuno - Seroprevalencia - Serotipo - Virus.

\section{References}

1. Sidibé A.S. (2003). - Les apports de l'assurance qualité à une organisation nationale vétérinaire dans les pays en développement : le cas de l'Afrique. In Veterinary Services: organisation, quality assurance and evaluation (E. Correa Melo \& F. Gerster, eds). Rev. Sci. Tech. Off. Int. Epiz., 22 (2), 679-688. doi:10.20506/rst.22.2.1421.

2. Food and Agriculture Organization of the United Nations (FAO) (2012). - FAO statistical yearbook 2012. FAO, Rome, Italy, 362 pp. Available at: www.fao.org/docrep/015/ i2490e/i2490e00.htm (accessed on 13 July 2018).

3. Food and Agriculture Organization of the United Nations (FAO) (2012). - État des lieux de l'élevage et des industries animales dans les pays de l'Afrique centrale. République du Tchad. FAO Subregional Office for Central Africa, Libreville, Gabon, 107 pp. Available at: https:// fr.scribd.com/document/140153262/Etat-des-lieux-ElevageTchad-dec-2012-ver-def-docx (accessed on 13 July 2018).

4. Ministry of Livestock and Animal Resources, Chad (2008). Plan national de développement de l'élevage (2009-2016). Ministry of Livestock and Animal Resources, N'Djamena, Chad, 82 pp. Available at: www.eeas.europa.eu/archives/delegations/ tchad/documents/more_info/pnde_version_20juin08_mf2_ compresse_fr.pdf (accessed on 13 July 2018).

5. Ouagal M., Hendrikx P., Saegerman C. \& Berkvens D. (2010). - Comparison between active and passive surveillance within the network of epidemiological surveillance of animal diseases in Chad. Acta Trop., 116 (2), 147-151. doi:10.1016/j. actatropica.2010.07.004.
6. Ouagal M., Brocchi E., Grazioli S., Ben Youssef A., Sumption K., Hendrikx P., Berkvens D. \& Saegerman C. (2017). - Évaluation de la sensibilité du réseau d'épidémiosurveillance des maladies animales au Tchad pour la surveillance de la fièvre aphteuse. Épidémiol. Santé Anim., 2017 (72), 5-14. Available at: http://aeema.vet-alfort.fr/index.php/2013-04-1200-44-00/epidemiologie-et-sante-animale/2017/783-201772-sommaire (accessed on 13 July 2018).

7. Kasambula L., Belsham G.J., Siegismund H.R., Muwanika V.B., Ademun-Okurut A.R. \& Masembe C. (2012). - Serotype identification and VP1 coding sequence analysis of foot-andmouth disease viruses from outbreaks in eastern and northern Uganda in 2008/9. Transbound. Emerg. Dis., 59 (4), 323-330. doi:10.1111/j.1865-1682.2011.01276.x.

8. World Organisation for Animal Health (OIE) (2013). - Foot and mouth disease portal. Available at: www.oie.int/animalhealth-in-the-world/fmd-portal/about-fmd/ (accessed on 13 July 2018).

9. Souley Kouato B., Mpolokang Fana E. [...] \& Saegerman C. (2018). - Outbreak investigations and molecular characterization of foot-and-mouth disease viruses circulating in southwest Niger. Transbound. Emerg. Dis., 65 (1), 146-157. doi:10.1111/tbed.12642.

10. Vosloo W., Bastos A., Sangare O., Hargreaves S. \& Thomson G. (2002). - Review of the status and control of foot-and-mouth disease in sub-Saharan Africa. Rev. Sci. Tech. Off. Int. Epiz., 21 (3), 437-449. doi:10.20506/rst.21.3.1349. 
11. Di Nardo A., Knowles N. \& Paton D. (2011). - Combining livestock trade patterns with phylogenetics to help understand the spread of foot and mouth disease in sub-Saharan Africa, the Middle East and Southeast Asia. In The spread of pathogens through international trade in animals and animal products (S. MacDiarmid, ed.). Rev. Sci. Tech. Off. Int. Epiz., 30 (1), 63-85. doi:10.20506/rst.30.1.2022.

12. Di Nardo A., Libeau G., Chardonnet B., Chardonnet P., Kock R.A., Parekh K., Hamblin P., Li Y., Parida S. \& Sumption K.J. (2015). - Serological profile of foot-and-mouth disease in wildlife populations of West and Central Africa with special reference to Syncerus caffer subspecies. Vet. Res., 46 (1), 77. doi:10.1186/s13567-015-0213-0.

13. Maree F., Kasanga C., Scott K., Opperman P., Chitray M., Sangula A., Sallu R., Sinkala Y., Wambura P., King D., Paton D. \& Rweyemamu M. (2014). - Challenges and prospects for the control of foot-and-mouth disease: an African perspective. Vet. Med. Res. Rep., 2014 (5), 119-138. doi:10.2147/VMRR.S62607.

14. Couacy-Hymann E., Aplogan G.-L., Sangaré O., Compaoré Z., Karimu J., Awoueme K.A., Seini A., Martin V. \& Valarcher J.-F. (2006). - Étude rétrospective de la fièvre aphteuse en Afrique de l'Ouest de 1970 à 2003. Rev. Sci. Tech. Off. Int. Epiz., 25 (3), 1013-1024. doi:10.20506/rst.25.3.1709.

15. Domenech J. (2011). - Mise en oeuvre d'une stratégie mondiale pour le contrôle de la fièvre aphteuse. In Final report of the 79th OIE General Session, 22-27 May 2011. OIE, Paris, France, 11 pp. Available at: www.oie.int/doc/ged/D10456.PDF (accessed on 13 July 2018).

16. Knight-Jones T.J.D., McLaws M. \& Rushton J. (2017). - Footand-mouth disease impact on smallholders - what do we know, what don't we know and how can we find out more? Transbound. Emerg. Dis., 64 (4), 1079-1094. doi:10.1111/ tbed. 12507.

17. Thomson G. \& Bastos A. (2004). - Foot-and-mouth disease. In Infectious diseases of livestock (J. Coetzer \& R. Tustin, eds), 2nd Ed., Vol. 2. Oxford University Press, Oxford, United Kingdom, 1324-1365.

18. Jemberu W.T., Mourits M.C.M., Sahle M., Siraw B., Vernooij J.C. \& Hogeveen H. (2015). - Epidemiology of foot and mouth disease in Ethiopia: a retrospective analysis of district level outbreaks, 2007-2012. Transbound. Emerg. Dis., 63 (6), e246-e259. doi:10.1111/tbed.12338.

19. Food and Agriculture Organization of the United Nations (FAO) \& World Organisation for Animal Health (OIE) (2013). - Approche progressive de la lutte contre la fièvre aphteuse (PCP-FMD). Principes directeurs, description des étapes et conditions à remplir. FAO, Rome, Italy, \& OIE, Paris, France, 22 pp. Available at: www.fao.org/fileadmin/user_upload/ eufmd/docs/PCP/FrenchEdited.pdf_(accessed on 13 July 2018).
20. Tounkara K., Couacy-Hymann E., Awuni J. \& Traore A. (2012). - Foot and mouth disease in West and Central Africa. In Proc. FAO/OIE Global Conference on Foot and Mouth Disease Control, 27-29 June 2012, Bangkok, Thailand. OIE, Paris, France, 163-172. Available at: www.oie.int/esp/E_ FMD2012/FAO\%20OIE\%20Global\%20Conference\%20 2012\%20in\%20Thailand/Day_2/1605-1620\%20Karim\%20 Tounkara.pdf (accessed on 13 July 2018).

21. Ouagal M., Hendrikx P., Berkvens D., Ncharé A., Cissé B., Akpeli P.Y., Sory K. \& Saegerman C. (2008). - Les réseaux d'épidémiosurveillance des maladies animales en Afrique francophone de l'Ouest et du Centre. Rev. Sci. Tech. Off. Int. Epiz., 27 (3), 689-702. doi:10.20506/rst.27.3.1828.

22. Laboratoire de recherches vétérinaires et zootechniques de Farcha (LRVZ) (2003). - Rapport national sur les ressources zoogénétiquesdu Tchad. LRVZ, Farcha, Chad, 78pp. Availableat: https://books.google.be/books/about/Rapport_national_sur_ les_ressources_zoog.html?id=d2HVAQAACAAJ\&redir_esc=y (accessed on 13 July 2018).

23. Brocchi E., Bergmann I.E. [...] \& De Clercq K. (2006). Comparative evaluation of six ELISAs for the detection of antibodies to the non-structural proteins of foot-and-mouth disease virus. Vaccine, 24 (47-48), 6966-6979. doi:10.1016/j. vaccine.2006.04.050.

24. Brocchi E., De Simone F., Bugnetti M., Gamba D. \& Capucci L. (1990). - Application of a monoclonal antibodybased competition ELISA to the measurement of anti-FMDV antibodies in animal sera. In Report of the session of the Research Group of the Standing Technical Committee of the European Commission for the Control of Foot-and-Mouth Disease, 25-29 June 1990, Lindholm, Denmark. FAO, Rome, Italy, 83-88. Available at: http://agris.fao.org/agris-search/ search.do?recordID=XF9107935 (accessed on 13 July 2018).

25. Brocchi E., Gamba D., Poumarat F., Martel J.L. \& De Simone F. (1993). - Improvements in the diagnosis of contagious bovine pleuropneumonia through the use of monoclonal antibodies. In Biotechnology applied to the diagnosis of animal diseases. Rev. Sci. Tech. Off. Int. Epiz., 12 (2), 559-570. doi:10.20506/ rst.12.2.702.

26. Brocchi E., Berlinzani A., Gamba D. \& De Simone F. (1995). Development of two novel monoclonal antibody-based ELISAs for the detection of antibodies and the identification of swine isotypes against swine vesicular disease virus. J. Virol. Meth., 52 (1-2), 155-167. doi:10.1016/0166-0934(94)00158-D.

27. Brocchi E., Grazioli S., Yadin H. \& De Simone F. (2004). Validation of a solid phase competitive ELISA (SPBE) based on the use of a single neutralising monoclonal antibody for the measurement of antibodies to FMDV type Asia 1. In Report of the Session of the Research Group of the Standing Technical Committee of the European Commission for the Control of Footand-Mouth Disease, 11-15 October, Chania, Crete, Greece, 288-297. Available at: www.fao.org/ag/againfo/commissions/ docs/greece04/app45.pdf (accessed on 13 July 2018). 
28. Grazioli S., Brocchi E., Tranquillo V., Parida S. \& Paton D. (2008). - Development of solid phase competitive ELISAs based on monoclonal antibodies for the serology of FMDV serotypes SAT1 and SAT2. In Report of the session of the Research Group of the Standing Technical Committee of the European Commission for the Control of Foot-and-Mouth Disease, 13-17 October, Erice, Italy, 267-276. Available at: www.fao.org/ag/againfo/commissions/docs/research_group/ erice/ppt_47.pdf (accessed on 13 July 2018).

29. StataCorp (2015). - Stata: Release 14.2. Statistical software. StataCorp LP, College Station, Texas, United States of America.

30. Rweyemamu M., Roeder P., Mackay D., Sumption K., Brownlie J., Leforban Y., Valarcher J.F., Knowles N.J. \& Saraiva V. (2008). - Epidemiological patterns of foot-andmouth disease worldwide. Transbound. Emerg. Dis., 55 (1), 57-72. doi:10.1111/j.1865-1682.2007.01013.x.

31. Mohamoud A., Tessema E. \& Degefu H. (2011). Seroprevalence of bovine foot-and-mouth disease (FMD) in Awbere and Babille districts of Jijiga zone, Somalia Regional State, Eastern Ethiopia. Afr. J. Microbiol. Res., 5 (21), 3559-3563. doi:10.5897/AJMR11.750.

32. Grant C.F., Carr B.V., Kotecha A., van den Born E., Stuart D.I., Hammond J.A. \& Charleston B. (2017). - The B cell response to foot-and-mouth disease virus in cattle following sequential vaccination with multiple serotypes. J. Virol., 91 (9), e02157-16. doi:10.1128/JVI.02157-16.
33. Bronsvoort B.M.D.C., Radford A.D., Tanya V.N., Nfon C., Kitching R.P. \& Morgan K.L. (2004). - Molecular epidemiology of foot-and-mouth disease viruses in the Adamawa province of Cameroon. J. Clin. Microbiol., 42 (5), 2186-2196. doi:10.1128/ JCM.42.5.2186-2196.2004.

34. Ludi A., Ahmed Z., Pomeroy L.W., Pauszek S.J., Smoliga G.R., Moritz M., Dickmu S., Abdoulkadiri S., Arzt J., Garabed R. \& Rodriguez L.L. (2016). - Serotype diversity of foot-andmouth-disease virus in livestock without history of vaccination in the far north region of Cameroon. Transbound. Emerg. Dis., 63 (1), e27-e38. doi:10.1111/tbed.12227.

35. Namatovu A., Tjørnehøj K., Belsham G.J., Dhikusooka M.T., Wekesa S.N., Muwanika V.B., Siegismund H.R. \& Ayebazibwe C. (2015). - Characterization of foot-and-mouth disease viruses (FMDVs) from Ugandan cattle outbreaks during 2012-2013: evidence for circulation of multiple serotypes. PLoS ONE, 10 (2), e0114811. doi:10.1371/journal. pone.0114811. 